\title{
Effect of Saiboku-to, an Antiasthmatic Herbal Medicine, on Nitric Oxide Generation from Cultured Canine Airway Epithelial Cells
}

\author{
Jun Tamaoki, Mitsuko Kondo, Atsushi Chiyotani, Hisashi Takemura and Kimio Konno \\ First Department of Medicine, Tokyo Women's Medical College, Tokyo 162, Japan \\ Received March 13, 1995 Accepted June 13, 1995
}

\begin{abstract}
The effect of Saiboku-to (TJ-96), an antiasthmatic Kampo medicine, on the generation of nitric oxide (NO) from cultured canine tracheal epithelium was investigated using a highly specific amperometric sensor for this molecule in vitro. Immersion of the NO-selective electrode in the medium containing tracheal epithelial cells detected the baseline current of $16.8-57.0 \mathrm{pA}$, which corresponded to an NO concentration ([NO]) of $39.7 \pm 8.1 \mathrm{nM}$. Addition of TJ-96 increased [NO] in a concentration-dependent manner, the maximal increase from the baseline level and the concentration of TJ-96 required to produce a half-maximal effect $\left(\mathrm{EC}_{50}\right)$ being $127.5 \pm 20.1 \mathrm{nM}(\mathrm{P}<0.001)$ and $86 \pm 9 \mu \mathrm{g} / \mathrm{ml}$, respectively. Pretreatment of cells with $N^{G}$-nitro-L-arginine methylester (L-NAME) greatly inhibited the TJ-96-induced increase in [NO], whereas $N^{G}$-nitro-D-arginine methylester (D-NAME) had no effect, and this inhibition was reversed by L-arginine but not by $D$-arginine. Cytochemical staining of the epithelial cells showed marked reactivity of NADPH diaphorase activity. These results suggest that NO is spontaneously released by the airway epithelium and that TJ-96 stimulates the epithelial NO generation.
\end{abstract}

Keywords: Chinese medicine, Airway epithelium, Nitric oxide, Asthma

Nitric oxide (NO) is now recognized as an important endogenous multifunctional bioregulatory molecule generated from the amino acid $\mathrm{L}$-arginine by nitric oxide synthase (NOS) (1). In the respiratory system, the localization of NOS-like immunoreactivity has been found in a variety of cell types such as endothelial cells, alveolar macrophages, autonomic neurons and airway epithelial cells (2). There is increasing evidence that NO may play a role in the regulation of airway and vascular smooth muscle tone, pulmonary neurotransmission, mucociliary transport and host defense $(3,4)$. Recent studies have shown that NO is present in the exhaled air of various species including humans $(5,6)$ and that the airway epithelium may be functioning in the protection against development of airway hyperresponsiveness, a characteristic feature of asthma (7), through the synthesis of NO (8).

Saiboku-to (TJ-96) is a traditional Chinese herbal medicine that has been widely used in the treatment of asthma in Asian countries. This drug modifies allergic events by inhibiting IgE-mediated release of histamine from basophils (9) and the release of platelet-activating factor from neutrophils (10) and by preventing downregulation of glucocorticoid and $\beta$-adrenergic receptors (11). Additionally, TJ-96 has been reported to stimulate ciliary motility (12) and $\mathrm{Na}$ absorption (13) in cultured airway epithelial cells. However, it is unknown whether this herbal medicine alters airway epithelial NO generation. Therefore, in the present study, we investigated the effect of TJ-96 on the generation of NO from cultured canine tracheal epithelium by a direct measurement of NO using a highly specific amperometric sensor for this molecule in vitro.

\section{MATERIALS AND METHODS}

\section{Preparation of epithelium}

Mongrel dogs of either sex, weighing 21 to $38 \mathrm{~kg}$ (SLC Japan, Hamamatsu), were anesthetized with intravenous pentobarbital sodium $(40 \mathrm{mg} / \mathrm{kg})$, and the trachea was rapidly removed. The tracheal mucosa was dissected from the underlying connective tissue, rinsed several times with sterile phosphate-buffered saline (PBS), and enzymatically digested with $0.1 \%$ protease type XIV (Sigma Chemical Co., St. Louis, MO, USA) at $4^{\circ} \mathrm{C}$ for $24 \mathrm{hr}$. After mild agitation, the tissue sections were removed from the medium, and the cells were concentrated by centrifugation $(800 \times g, 10 \mathrm{~min})$. The cell pellets were washed with medium containing $5 \%$ fetal calf serum to neutralize the 
protease. These cells were suspended in a mixture of DMEM and Ham's F-12 containing 5\% fetal calf serum, $100 \mathrm{U} / \mathrm{ml}$ each of penicillin and streptomycin, $100 \mu \mathrm{g} / \mathrm{ml}$ gentamicin, $10 \mu \mathrm{g} / \mathrm{ml}$ insulin, $5 \mu \mathrm{g} / \mathrm{ml}$ transferrin, 25 $\mathrm{ng} / \mathrm{ml}$ epidermal growth factor and $7.5 \mu \mathrm{g} / \mathrm{ml}$ endothelial cell growth supplement. Our preliminary studies showed that this preparation of cells was composed of $97-99 \%$ epithelial cells and 1-3\% fibroblasts and other nonepithelial cells, and the viability was between $89 \%$ and $96 \%$, as assessed by trypan blue exclusion. We plated the cells at a density of $1.5 \times 10^{6} / \mathrm{cm}^{2}$ on a coverglass $(18 \times 24 \mathrm{~mm})$ coated with human placental collagen $(5.8$ $\mu \mathrm{g} / \mathrm{cm}^{2}$, Sigma) in a Petri dish and cultured them at $37^{\circ} \mathrm{C}$ in a $\mathrm{CO}_{2}$ incubator $\left(95 \%\right.$ air $\left.-5 \% \mathrm{CO}_{2}\right)$. The medium was changed every $24 \mathrm{hr}$ and on the seventh day of incubation, the tracheal epithelial cells were used for the measurement of NO generation. Our separate studies on transmission electron microscopy showed that this preparation was a monolayer culture in which non-ciliated cells containing microvilli and glycocalyx constituted more than $99 \%$ of the total. Moreover, we have previously shown that these cultured cells maintain, at least, bioelectric properties similar to those of native tissues (13).

\section{Measurement of NO generation}

The measurement of NO generation using the NOselective electrode has been described in detail previously $(14,15)$. Briefly, a coverglass on which the tracheal epithelial cells were grown was mounted in a glass chamber filled with $10 \mathrm{ml} \mathrm{Krebs-Henseleit}(\mathrm{KH})$ solution of the following composition: $143.9 \mathrm{mM} \mathrm{Na}, 5.6 \mathrm{mM} \mathrm{K}, 1.9$ $\mathrm{mM} \mathrm{Ca}, 1.2 \mathrm{mM} \mathrm{Mg}, 117.6 \mathrm{mM} \mathrm{Cl}, 25.0 \mathrm{mM} \mathrm{HCO}_{3}, 5.6$ $\mathrm{mM}$ acetate, $3.8 \mathrm{mM}$ gluconate, $1.3 \mathrm{mM} \mathrm{H}_{2} \mathrm{PO}_{4}, 1.2 \mathrm{mM}$ $\mathrm{SO}_{4}$ and $5.6 \mathrm{mM}$ glucose, continuously stirred and maintained at $37^{\circ} \mathrm{C}$ by a water-jacketed perfusion apparatus (model 5301; Yellow Springs Instruments Co., Ltd., Yellow Springs, OH, USA). The concentration of NO ([NO]) in the medium bathing the cells was determined by an NO meter (NO-501; Inter Medical Co., Ltd., Tokyo). The principle of the NO meter is based on the measurement of pA-order redox current between the working electrode and the counter electrode: the working electrode consisted of a 0.2-mm diam Pt/ Ir alloy wire (Pt 90\%, Ir 10\%) coated with a three-layered membrane consisting of $\mathrm{KCl}$, NO-selective resin, and normal silicon membranes, and the counter electrode was made of carbon fiber. The $\mathrm{KCl}$ membrane was electrochemically deposited on the $\mathrm{Pt} / \mathrm{Ir}$ wire to suppress overvoltage in the discharge of NO. The NO-selective resin was coated by $0.8 \%$ nitrocellulose, and the outermost membrane was introduced to avoid a nonspecific ionic effect and electrochemical reactions. The working electrode was supplied with 0.4 to $0.8 \mathrm{~V}$ for the electrochemical oxidation of NO. This resulting polaro- graphic current was detected with a current-voltage counter circuit in a high input impedance preamplifier placed near the electrode pair. The current flow was proportional to the rate of diffusion of NO through the membrane, which was in turn proportional to $[\mathrm{NO}]$ at the outer surface of the membrane. Thus, to assess the generation of NO by the tracheal epithelium, both working and counter electrodes were immersed in the medium, and the current was continuously recorded on a pen recorder (SR-6355; Graphtec, Tokyo).

Calibration of the electrode was performed daily prior to the experiments. Using the nitrosothiol NO donor $S$ nitroso- $N$-acetyl-DL-penicillamine (SNAP) as a standard (16), the relationship between the magnitude of electrical current recorded and the concentration of SNAP in KH solution was determined (Fig. 1). The current increased linearly as the SNAP concentration increased. The [NO] can be determined from the concentration of SNAP based on the facts that SNAP is decomposed thermally according to first-order kinetics (17) and that the reaction of liberated $\mathrm{NO}$ with $\mathrm{O}_{2}$ occurs with third-order kinetics (18). The signal-to-noise ratio ( $\mathrm{S} / \mathrm{N})$ was approximately 1 when $5 \mu \mathrm{M}$ SNAP, which corresponded to $6.5 \mathrm{nM}$ NO (14), was applied. When $0.1 \mathrm{mM}$ SNAP, which corresponded to $130 \mu \mathrm{M}$ NO, was added, the $\mathrm{S} / \mathrm{N}$ was greater than 60 . To test the selectivity of the electrode, we performed a preliminary study on the effects of $\mathrm{NO}_{2}{ }^{-}$and $\mathrm{NO}_{3}{ }^{-}$, which are reaction products of $\mathrm{NO}$ and $\mathrm{O}_{2}$, and found that these molecules did not affect the electrode current. Because heat-decomposed SNAP exhibited only

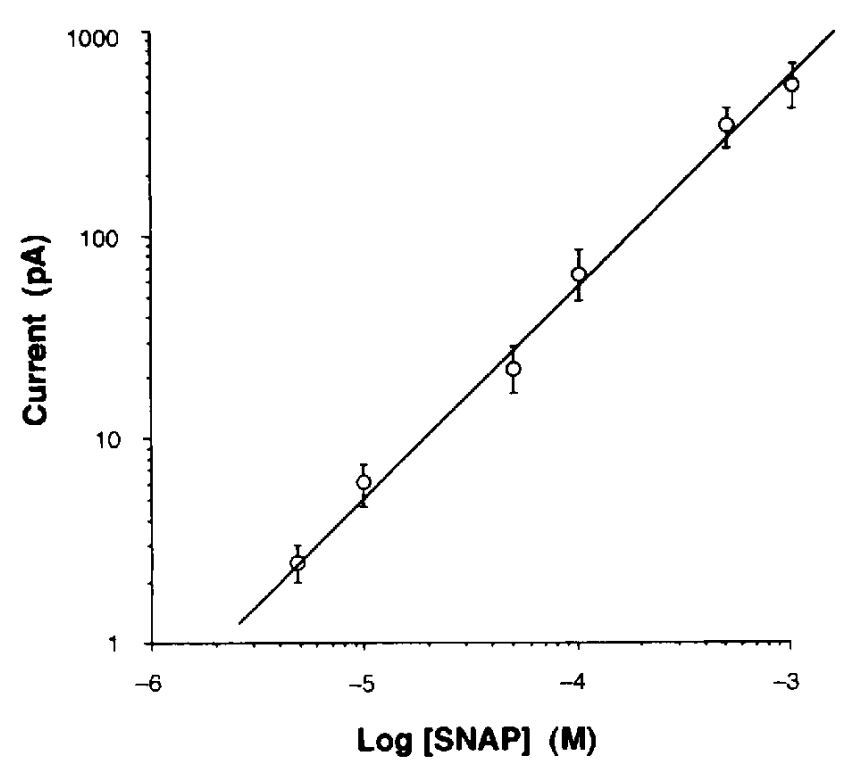

Fig. 1. Relationship between the concentration of $S$-nitroso- $N$ acetyl-DL-penicillamine (SNAP) in Krebs-Henseleit solution at $37^{\circ} \mathrm{C}$ and the electrical current detected by a nitric oxide-selective electrode. Data are means \pm S.E.M., $n=18-26$ for each point. 
$2 \%$ of the original current and because the NO scavengers oxyhemoglobin $\left(4 \times 10^{-6} \mathrm{M}\right)$ and 2-phenyl-4,4,5,5tetramethylimidazole-3-oxide-1-oxyl (PTIO, $3 \times 10^{-5} \mathrm{M}$ ) suppressed the SNAP $\left(5 \times 10^{-5} \mathrm{M}\right)$-induced current by $94 \pm 3 \%(n=6)$ and $89 \pm 7 \%(n=5)$, respectively, there seemed no significant direct effect of SNAP itself on the electrode current.

\section{Effect of TJ-96 on NO release}

The electrodes were transferred from $\mathrm{KH}$ solution without cells in which the electrical current was zero into the solution bathing the cells in the chamber, and the current was measured. When the baseline current became stable, TJ-96 $(100 \mu \mathrm{g} / \mathrm{ml})$ or its vehicle (PBS) alone was added to the chamber and the response was monitored at least for $10 \mathrm{~min}$. To confirm whether the response of the current was actually due to the released NO, the cells were incubated for $15 \mathrm{~min}$ with either $N^{G}$-nitro-D-arginine methylester (D-NAME, $10^{-3} \mathrm{M}$ ) or $N^{G}$-nitro-L-arginine methylester (L-NAME, $10^{-3} \mathrm{M}$ ), an inhibitor of NOS (19), and TJ-96 $(100 \mu \mathrm{g} / \mathrm{ml})$ was subsequently added to the chamber. Then, after the response to TJ-96 reached a plateau, $\mathrm{D}$-arginine and $\mathrm{L}$-arginine at $10^{-3} \mathrm{M}$ were consecutively added.

We also examined the concentration-dependent effect of TJ-96 on NO generation. TJ-96 was added to the chamber in the absence and presence of $10^{-3} \mathrm{M}$ D-NAME or L-NAME in a cumulative manner from 1 to 1000 $\mu \mathrm{g} / \mathrm{ml}$, and the highest recorded value of the current in response to each concentration was determined.

\section{Cytochemistry of NADPH diaphorase}

Since all the NOSs characterized to date are active in histochemical assay for NADPH diaphorase (20), we examined the existence of NOS in cultured canine tracheal epithelial cells by cytochemical staining of NADPH diaphorase activity. The cells grown on a coverglass were fixed in fresh $2 \%$ buffered paraformaldehyde for $10 \mathrm{~min}$ and rinsed with PBS. The coverglass was then immersed in a reaction mixture consisting of $0.25 \mathrm{mg} / \mathrm{ml}$ nitroblue tetrazoium, $1 \mathrm{mg} / \mathrm{ml}$ NADPH and $0.5 \%$ Triton X-100 in $0.1 \mathrm{M}$ Tris buffer at $\mathrm{pH}$ 7.6. After $30 \mathrm{~min}$, the cells were washed with PBS, and NADPH diaphorase staining was assessed by a microscope at a magnification of $\times 200$. In the control experiment, the substrate was omitted in the reaction medium and $p$-nitrophenylphosphate $(1.5 \times$ $10^{-3} \mathrm{M}$ ) was included to inhibit endogenous phosphatases that may convert NADPH to NADH and cause false-positive staining by NADH dehydrogenases (21).

\section{Drugs}

The following drugs were used: TJ-96 (extract granules; Tsumura Co., Tokyo), SNAP, PTIO (Inter Medical Co., Ltd.), oxyhemoglobin, L-NAME, D-NAME, L-arginine, D-arginine, nitroblue tetrazoium, NADPH, $p$-nitrophenylphosphate (Sigma). TJ-96 was dissolved in PBS at $1 \mathrm{mg} / \mathrm{ml}$, vortexed for $30 \mathrm{~min}$, and centrifuged $(200 \times \mathrm{g}$, $10 \mathrm{~min}$ ). Then the supernatant was taken and passed

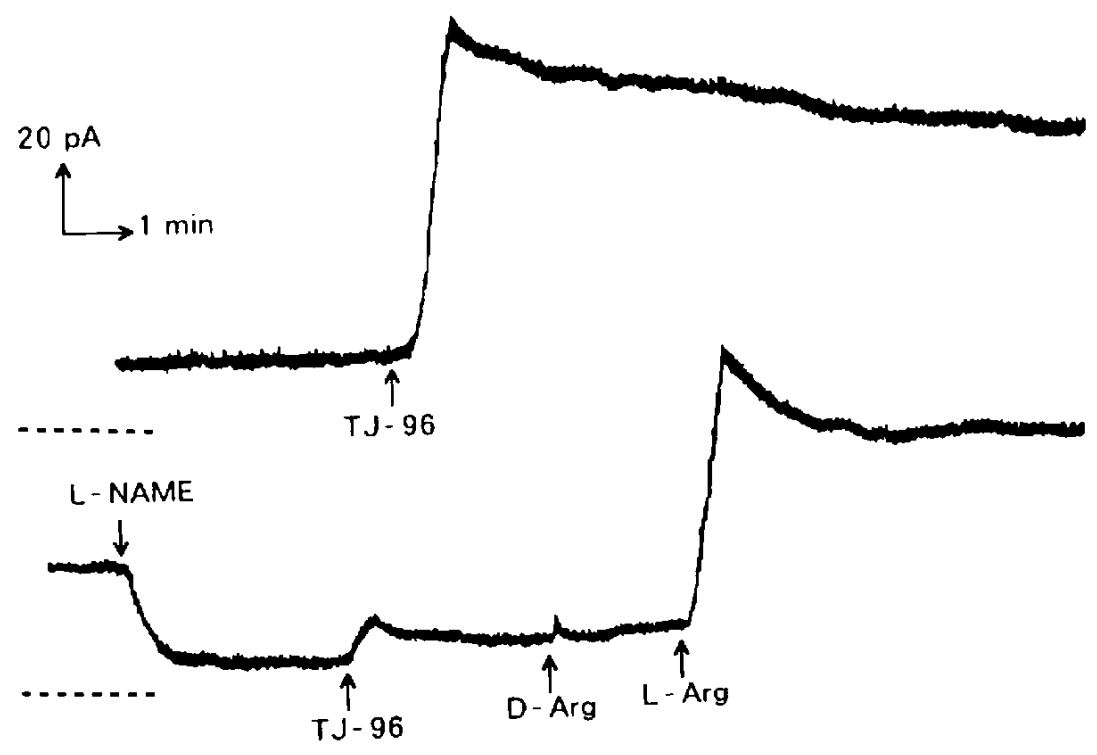

Fig. 2. Representative tracing of electrical current in the Krebs-Henseleit solution bathing the cultured canine tracheal epithelial cells. After equilibration, TJ-96 $(100 \mu \mathrm{g} / \mathrm{ml})$ was added to the chamber in the absence (upper panel) and presence of $N^{G}$-nitro-L-arginine methylester (L-NAME, $10^{-3} \mathrm{M}$, lower panel). When the response reached a plateau, D-arginine (D-Arg, $10^{-3} \mathrm{M}$ ) and L-arginine (L-Arg, $10^{-3} \mathrm{M}$ ) were consecutively added. ( $\cdots \cdots$ : zero current). Typical of 10 and 8 experiments for upper panel and lower panel, respectively. 
through a millipore filter (pore size, $0.45 \mu \mathrm{m}$ ); this filtered supernatant was used for the experiments on NO generation.

\section{Statistics}

All values are expressed as means \pm S.E.M. Statistical analysis was performed by ANOVA, and a $P$ value of less than 0.05 was considered statistically significant.

\section{RESULTS}

\section{Generation of NO}

The polarographic current detected by the NO-selective electrode in the KH solution bathing the cultured canine tracheal epithelium is shown in Fig. 2. Immersion of both the working and counter electrodes in the incubation medium produced a baseline current with a variation of $16.8-57.0 \mathrm{pA}$, which corresponded to [NO] at $39.7 \pm 8.1$ $\mathrm{nM}(\mathrm{n}=14)$. Addition of TJ-96 $(100 \mu \mathrm{g} / \mathrm{ml})$ elicited an increase in the current that peaked within $1 \mathrm{~min}$ $(42.2 \pm 7.0$ to $133.6 \pm 18.5 \mathrm{pA}, \mathrm{P}<0.001, \mathrm{n}=10)$ and gradually decreased during the 10 -min observation period. Pretreatment of cells with L-NAME $\left(10{ }^{3} \mathrm{M}\right)$ per se reduced the baseline current from $44.7 \pm 6.8$ to $8.1 \pm 3.3 \mathrm{pA}(\mathrm{P}<0.001, \mathrm{n}=8)$ and inhibited the response to $\mathrm{TJ}-96(100 \mu \mathrm{g} / \mathrm{ml})$ by approximately $86 \%(\mathrm{P}<0.001)$, whereas D-NAME $\left(10^{-3} \mathrm{M}\right)$ had no such effects. This inhibition of the current by L-NAME was restored by the subsequent addition of L-arginine $\left(10^{-3} \mathrm{M}\right)$, but not by $\mathrm{D}-$ arginine $\left(10^{-3} \mathrm{M}\right)$. As shown in Fig. 3, TJ-96 increased $[\mathrm{NO}]$ in a concentration-dependent manner, the maximal increase from the baseline level and the concentration of $\mathrm{TJ}-96$ required to produce a half-maximal effect $\left(\mathrm{EC}_{50}\right)$ being $127.5 \pm 20.1 \mathrm{nM} \quad(\mathrm{P}<0.001)$ and $86 \pm 9 \mu \mathrm{g} / \mathrm{ml}$, respectively $(\mathrm{n}=12)$. This effect of TJ-96 on NO generation was greatly attenuated by L-NAME but not by DNAME.

\section{NADPH diaphorase activity}

Cultured canine tracheal epithelial cells showed marked reactivity to NADPH diaphorase staining, where the labeling was confined to the cytoplasmic region, leaving the nucleus unstained. In contrast, no staining was observed in the control experiment in which the substrate was omitted from the reaction medium (Fig. 4).

\section{DISCUSSION}

Our in vitro studies demonstrate that cultured canine tracheal epithelial cells are spontaneously generating NO under baseline conditions and that this generation is stimulated by Saiboku-to, TJ-96, a Chinese antiasthmatic herbal medicine.

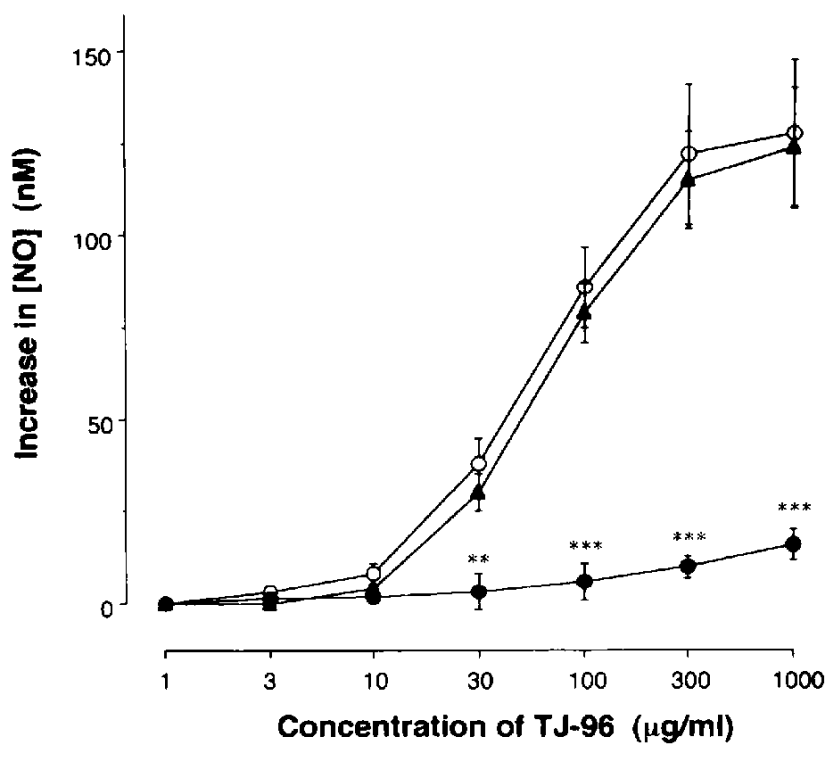

Fig. 3. Concentration-dependent effects of TJ-96 on release of nitric oxide (NO). TJ-96 was cumulatively added to Krebs-Henseleit solution bathing the cultured canine tracheal epithelium in the absence (control, open circles) and presence of $N^{G}$-nitro-D-arginine methylester (D-NAME, $10^{-3} \mathrm{M}$; closed triangles) or $N^{G}$-nitro-Larginine methylester (L-NAME, $10^{-3} \mathrm{M}$; closed circles). Responses are expressed as the increase in the concentration of NO ([NO]) in the solution. Data are means \pm S.E.M., $\mathrm{n}=12$ for each point. ${ }^{* *} \mathrm{P}<0.01,{ }^{* * *} \mathrm{P}<0.001$, significantly different from control values.

The multipurpose messenger molecule NO is generated from the amino acid $\mathrm{L}$-arginine by NOS and has been identified as part of the transduction mechanism of the soluble guanylyl cyclase and also as an immunologically derived effector molecule. In the respiratory tract, endothelial cells (22), vascular smooth muscle cells (23), mast cells (24), alveolar macrophages (25), polymorphonuclear leukocytes (26) and epithelial cells (2) are potential sources of NO. The epithelial layer in asthmatic patients is often damaged, and the degree of epithelial damage is associated with the degree of airway hyperresponsiveness (27). A diminished production of epithelium-derived relaxing factors caused by the epithelial damage may contribute to the increased airway response in these patients. Nijkamp and coworkers (8) have recently shown that NO secreted by the airway epithelium may protect against the development of airway hyperresponsiveness. Therefore, stimulation of epithelial NO generation by TJ-96 seems desirable in the treatment of asthma.

Because NO is destroyed in less than a second by oxidation in the biological environment, the measurement of this molecule has been difficult. In most studies, the notion that NO is generated has been derived from the enantiomer specific effects of methylester derivatives of arginine analogues including L-NAME, but this conclu- 

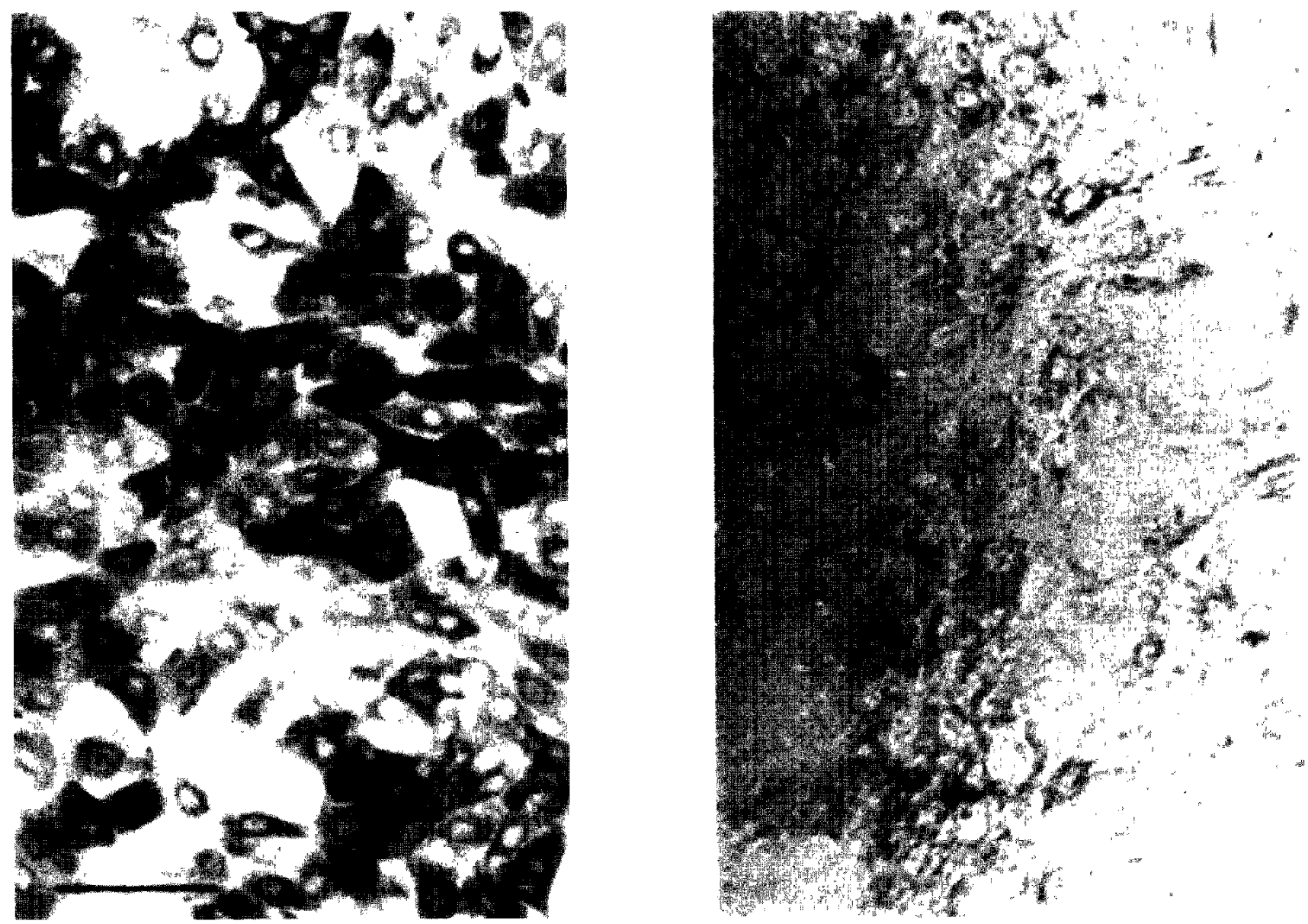

Fig. 4. Histochemical staining with NADPH diaphorase activity showing a strong blue reaction product in cultured canine tracheal epithelium (left panel). In the control experiment, NADPH was omitted and $p$-nitrophenylphosphate was included in the reaction medium (right panel). Calibration bar $=15 \mu \mathrm{m}$. Typical of 14 experiments for each.

sion is based on the premise that these drugs are specific inhibitors of NOS. Moreover, although the concentration of NO in exhaled air has recently been measured by a chemiluminescence analyzer $(6,28)$, this method, which requires purging the sample solution with inert gas to remove NO from its environment, is tedious and time-consuming and, most importantly, does not permit quantification of NO in its physiological environment in the presence of other constituents. We thus adopted a recently-developed specific amperometric sensor for NO (14). In the present study, immersion of the NO-selective electrode in the solution bathing the canine tracheal epithelial cells detected the current, indicating that NO is spontaneously released by these cells. This notion is also supported by the finding that the cells showed a potent NADPH diaphorase activity, which reflects the existence of NOS (20). Addition of TJ-96 increased NO generation from the tracheal epithelial cells in a concentration-dependent manner. Pretreatment of the cells with L-NAME greatly inhibited this increase, whereas D-NAME had no effect, and the L-NAME-induced inhibition was reversed by Larginine but not by $\mathrm{D}$-arginine.

TJ-96 is a blended medicine made from ten crude herbal drugs, and it is uncertain which crude drugs are responsible for epithelial NO generation. Bredt and colleagues (29) reported that NOS can be stoichiometrically phosphorylated by $\mathrm{Ca}^{2+} /$ calmodulin-dependent protein kinase II and cyclic AMP-dependent kinase, with each kinase phosphorylating a different site on this enzyme, and we have recently shown that intracellular accumulation of cyclic AMP but not elevation of $\mathrm{Ca}^{2+}$ concentration plays an important role in the generation of NO in canine airway epithelium (30). Although we did not assess the effect of TJ-96 on the cyclic AMP-dependent pathway in the present study, Zizyphi fructus, one of the constituents of TJ-96, exhibits cyclic AMP-like bioactivities (31), and TJ-96 is capable of increasing airway epithelial cyclic AMP contents (12). Therefore, we speculate that enhancement of cyclic AMP synthesis might be involved in the TJ-96-induced NO generation by airway epithelial cells. 


\section{Acknowledgments}

The authors thank Yoshimi Sugimura and Masayuki Shino for their technical assistance. We also thank Tsumura Co. for providing us with TJ-96. This work was supported in part by Grant for Scientific Research No.04670476 from the Ministry of Education, Science, Sports and Culture, Japan.

\section{REFERENCES}

1 Moncada S, Palmer RMJ and Higgs EA: Nitric oxide: physiology, pathophysiology, and pharmacology. Pharmacol Rev 43, $109-142$ (1991)

2 Kobzik L, Bredt DS, Lowenstein CJ, Drazen J, Gaston B, Sugarbaker D and Stamler JS: Nitric oxide synthase in human and rat lung: immunocytochemical and histochemical localization. Am J Respir Cell Mol Biol 9, 371-377 (1993)

3 Belvisi MG, Stretton CD, Yacoub $M$ and Barnes PJ: Nitric oxide is the endogenous neurotransmitter of bronchodilator nerves in humans. Eur J Pharmacol 210, 221-222 (1992)

4 Gaston B, Drazen JM, Loscalzo J and Stamler JS: The biology of nitric oxides in the airways. Am J Respir Crit Care Med 149, 538-551 (1994)

5 Gustafsson LE, Leone AM, Persson MG, Wilkund NP and Moncada S: Endogenous nitric oxide is present in the exhaled air of rabbits, guinea pigs and humans. Biochem Biophys Res Commun 181, 852-857 (1991)

6 Kharitonov SA, Yates D, Robbins RA, Logan-Sinclair R, Shinebourne EA and Barnes PJ: Increased nitric oxide in exhaled air of asthmatic patients. Lancet 343, 133-135 (1994)

7 Boushey HA, Holtzman MJ, Sheller JR and Nadel JA: State of the art: bronchial hyperreactivity. Am Rev Respir Dis 121, $389-413(1980)$

8 Nijkamp FP, Van Der Linde HJ and Folkers G: Nitric oxide synthesis inhibitors induce airway hyperresponsiveness in the guinea pig in vivo and in vitro: role of epithelium. Am Rev Respir Dis 148, $727-734$ (1993)

9 Koda A, Nishiyori T, Nagai $H$, Matsuura $N$ and Tsuchiya $H$ : Anti-allergic actions of crude drugs and blended Chinese traditional medicine: effect on type I and type IV allergic reactions. Folia Pharmacol Jpn 80, 31-41 (1982) (Abstr in English)

10 Miyamoto $T$, Takaishi $T$, Morita $H$, Kuriyama $M$ and Nakamura T: The actions of Saiboku-to (TJ-96) on histamine release and the production of platelet-activating factor in human leukocytes. In Medicines of Plant Origin in Modern Therapy: A Symposium Report, Edited by Miyamoto, T, pp 12-13, Oxford Clinical Communications, Oxford (1990)

11 Nakajima S, Doi Y, Yamasaki K, Tohda Y and Sunaga S: Effect of Saiboku-to (TJ-96) on beta receptors and steroid receptors. In Medicines of Plant Origin in Modern Therapy: A Symposium Report, Edited by Miyamoto, T, pp 16-17, Oxford Clinical Communications, Oxford (1990)

12 Takeyama K, Chiyotani A, Tamaoki J, Kanemura T, Takizawa $\mathrm{T}$ and Konno K: Effect of Saibokuto on mucociliary transport system in the airway. Jpn J Allergol 41, 43-48 (1992) (Abstr in English)

13 Tamaoki J, Takeyama K, Chiyotani A, Sakai N, Takizawa T

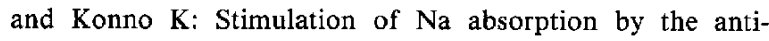
asthmatic Kampo drug Saiboku-to in cultured airway epithelium. Jpn J Pharmacol 58, 47-53 (1992)

14 Ichimori $\mathrm{K}$, Ishida $\mathrm{H}$, Fukabori $M$, Nakazawa $\mathrm{H}$ and
Murakami E: Practical nitric oxide measurement employing a nitric oxide-sensitive electrode. Rev Sci Instrum 65, 1-5 (1994)

15 Malinski $T$ and Taha $Z$ : Nitric oxide release from a single cell measured in situ by a porphyrinic-based microsensor. Nature 358, 676-678 (1992)

16 Boughton-Smith NK, Hutcheson IR, Deakin AM, Whittle BJR and Moncada S: Protective effect of $S$-nitroso- $N$-acetyl-penicillamine in endotoxin-induced acute intestinal damage in the rat. Eur J Pharmacol 191, $485-488$ (1990)

17 Feelisch M: The biochemical pathways of nitric oxide formation from nitrovasodilators: appropriate choice of exogenous NO donors and aspects of preparation and handling of aqueous NO solutions. J Cardiovasc Pharmacol 17, Supp 3, S25-S33 (1991)

18 Stedman DH and Niki H: Kinetics and mechanism for the photolysis of nitrogen dioxide in air. J Phys Chem 77, 2604-2609 (1973)

19 Rees DD, Palmer RMJ, Schulz R, Hodson HF and Moncada S: Characterization of three inhibitors of endothelial nitric oxide synthase in vitro and in vivo. $\mathrm{Br} \mathrm{J}$ Pharmacol 101, 746-752 (1990)

20 Schmidt H, Gagne G, Nakane M, Pollock J, Miller M and Murad F: Mapping of neural nitric oxide synthase in the rat suggest frequent co-localisation with NADPH diaphorase but not with soluble guanylyl cyclase, and novel paraneural functions for nitrinergic signal transduction. J Histochem Cytochem 40, $1439-1453$ (1992)

21 Leeflang-DePijper and Hulsman W: Pitfalls in histochemical localization studies of NADPH generating enzymes or enzyme systems in rat small intestine. Histochemistry 39, 143-153 (1974)

22 Palmer RMJ, Ferrige AG and Moncada S: Nitric oxide release accounts for the biological activity of endothelium-derived relaxing factor. Nature 327, 524-526 (1987)

23 Wood KS, Buga GM, Byrns RE and Ignarro LJ: Vascular smooth muscle-derived relaxing factor (MDRF) and its close similarity to nitric oxide. Biochem Biophys Res Commun 160, 813-819 (1990)

24 Salvemini D, Masini E, Anggard E, Mannaioni PF and Vane J: Synthesis of a nitric oxide-like factor from L-arginine by rat serosal mast cells: stimulation of guanylate cyclase and inhibition of platelet aggregation. Biochem Biophys Res Commun 169, 596-601 (1990)

25 Hibbs JBL, Taintor RR and Vavrin Z: Macrophage cytotoxicity: role of $\mathrm{L}$-arginine deaminase and imino nitrogen oxidation to nitrite. Science 235, 473-476 (1987)

26 Schmidt HHW, Seifert R and Bohme E: Formation and release of nitric oxide from human neutrophils and HL-60 cells induced by chemotactic peptides, platelet-activating factor and leukotriene $B_{4}$. FEBS Lett 244, 357-360 (1989)

27 Djukanovic R, Roche WR, Wilson JW, Beasley CRW, Twentyman OP, Howarth $\mathrm{PH}$ and Holgate ST: Mucosal inflammation in asthma. Am Rev Respir Dis 142, 434-457 (1989)

28 Persson MG, Zetterström $O$, Agrenius $V$, Ihre $E$ and Gustafsson LE: Single-breath nitric oxide measurements in asthmatic patients and smokers. Lancet 343, 146-147 (1994)

29 Bredt DS, Hwang PM, Glatt CE, Lowenstein C, Reed RR and Snyder SH: Cloned and expressed nitric oxide synthase structurally resembles cytochrome P-450 reductase. Nature 351, 
$714-718$ (1991)

30 Tamaoki J, Kondo M, Takemura $H$, Chiyotani A, Yamawaki I and Konno K: Cyclic AMP-mediated release of nitric oxide from canine cultured tracheal epithelium. Am J Respir Crit
Care Med (in press)

31 Cyong J-C, Hanabusa $\mathrm{K}$ and Otsuka Y: Studies on the cyclic AMP-like substance found in Zizyphi fructus. Wakan-Yaku 12, 1-7 (1979) (Abstr in English) 